\title{
PRELIMINARY PHYTOCHEMICAL SCREENING AND IN VITRO ANTIMICROBIAL ACTIVITY OF THE LEAF EXTRACT OF THUNBERGIA COCCINEA (FAMILY-ACANTHACEAE)
}

\author{
NARGIS SULTANA*, SUMIT DAS \\ Girijananda Chowdhury Institute of Pharmaceutical Science Azara, Guwahati, India \\ Email: nargissultana2017@gmail.com
}

Received: 15 Apr 2019, Revised and Accepted: 13 Jun 2019

\begin{abstract}
Objective: To estimate the antimicrobial activity of the leaf extract of Thunbergia coccinea in association with phytochemical analysis.

Methods: The extraction of the leaves of Thunbergia coccinea was done by using a various solvent like petroleum ether, chloroform and methanol. The phytochemical constitutes are investigated by using standard methods. Antimicrobial activity of leave extract was carried out against gram positive bacteria (Staphylococcus aureus) and one gram negative bacteria (Escherichia coli). The anti-fungal activity of the plant extract was evaluated on Candida albicans. The testing was done by using disc diffusion method. The zone of inhibition was compared with standard Amikacin for anti-bacterial activity and fluconazole for anti-fungal activity.
\end{abstract}

Results: The present investigation shows the phytochemical analysis which revealed the presence of alkaloid, flavonoid, cardiac glycoside, saponin glycoside, tannin and phenolics. The antimicrobial activity of plant extract is showed significant result against all three of the test organism.

Conclusion: The present study concluded that the leaf extract of Thunbergia coccinea contain various phytochemicals and possess promising antimicrobial activity when compared with the standards.

Keyword: Antimicrobial activity, Disc diffusion method, Phytochemicals, Zone of inhibition, Thunbergia coccinea

(C) 2019 The Authors. Published by Innovare Academic Sciences Pvt Ltd. This is an open access article under the CC BY license (http://creativecommons.org/licenses/by/4.0/) DOI: http://dx.doi.org/10.22159/ijcpr.2019v11i4.34938

\section{INTRODUCTION}

Medicinal plants have been used from the ancient time to prevent and treat various health problems. Plants are still an independent source of medication in the contemporary health care delivery system. Their role is twofold in the development of medicines and served as a natural blue print for the development of new drugs [1]. Plants used for traditional medicine contain a wide range of substances that can be used to treat chronic as well as communicable diseases. Medicinal plants represent a rich source of antimicrobial agents [2]. According to World Health Organization (WHO) more than $80 \%$ of the world's population relies on traditional medicine for their primary healthcare needs. Medical plants contain large varieties of chemical substances, which possess important therapeutic properties that could be utilized in the treatment of human diseases. Many plants have been used because of their antimicrobial traits, which are due to phytochemicals synthesized in the secondary metabolism of the plant $[3,4]$. Plants are rich in a wide variety of secondary metabolites such as tannins, alkaloids, phenolic compound and flavonoids, which have been found in vitro to have antimicrobial properties $[5,6]$.
Thunbergia is a genus of flowering plant of Acanthaceae family, native to tropical regions of Africa, Madagascar, Australia and South Asia. Thunbergia species include some 100 species of annuals, perennials and shrubs. There are many twinning climbers, as well as some shrubby types in this variable genus. Antibacterial, antifungal and anthelmintic activity of Thunbergia grandiflora, antiinflammatory, antitumor, antioxidant antinociceptive activity of Thunbergia laurifolia due to the presence of rosmarinic acid and also antidiabetic and hepatoprotective activity of Thunbergia laurifolia has been reported. The attractive climbers are a varied group usually with pointed oval to heart-shaped leaves, sometimes lobed or toothed. They occur in many colour but are most often yellow, orange and purple-blue shades. Many of the Thunbergia species prefer full sun and well-drained soil but can bloom in partial shade also. A sunny location is required as they can receive direct sunlight for six or more hours a day. Regular and deep watering is needed for the plants, allowing the soil to dry slightly between watering (but total dry soil will cause wilting and premature flower drops). Most of the plants of this genus have ornamental value but some of them have medicinal value also [7].

Table 1: Characteristic feature of Thunbergia coccinea

\begin{tabular}{ll}
\hline Common name & Scarlet vine, red clock vine \\
\hline Height: & $3-8$ meters \\
Plant type: & Perennial climbing vine \\
Root system: & Tuberous \\
Leaf arrangement: & Opposite \\
Leaf surface: & Both surfaces pubescent \\
Leaf shape: & Ovate or lanceolate \\
Flower: & Scarlet red with orange centre tubuler flower \\
Fruit: & Loculicidal capsule(glabrous) \\
Flowering: & November-March \\
Fruiting: & February-April \\
Distribution: & Assam and Meghalaya \\
\hline
\end{tabular}




\section{MATERIALS AND METHODS}

\section{Collection of plant materials}

The plant material was collected from Meghalaya, North East India The plant specimen was authenticated by Dr. N Devi, Professor and Head, Department of Botany, Gauhati University, Guwahati, Assam. The voucher specimen has been stored in the Herbarium of the Department of Botany, Gauhati University with Acc. No.-18493 dated 26-10-2018, for future reference.

\section{Chemicals and reagents}

Petroleum Ether, Methanol $\left(\mathrm{CH}_{3} \mathrm{OH}\right)$, Choloroform $\left(\mathrm{CHCl}_{3}\right)$, dimethyl sulfoxide (DMSO), hydrochloric acid, Dragondorff reagent, Mayer's reagent, Wagner's reagent, Millon's reagent, Ninhydrin reagent, sulfuric acid, lead acetate, Fehling solution A and B, 5\% iodine, ferric chloride, sodium hydroxide, glacial acetic acid, picric acid, ethyl acetate, benzene, ammonia, nitric acid, potassium hydroxide, Beef extract, Peptone and agar. All the chemicals and solvents used were of standard analytical grades.

\section{Preparation of the plant extract}

The leaves of plant sample were washed 2-3 times with running fresh water and air-dried under shade. After complete shade drying, the plant material was grinded with the mechanical grinder and the powder was kept in a tightly closed container. It was defatted with Petroleum Ether by using soxhlet apparatus and then extracted with chloroform and methanol in the order of their increasing polarity. The solution was filtered using Whatman filter paper and the filtrate was concentrated to a semi-solid residue and put away in the refrigerator for further anti-microbial analysis. The extract acquired was weighed and the rate yield was figured as per as the dried weight of the plant material utilizing the equation: Calculation of \% Yield $=$ (Dry weight of the extract/Dry weight of leaf sample) $\times 100$

\section{Phytochemical screening}

The plant extract was tested for the presence of alkaloids, saponin, flavonoids, carbohydrates, proteins and amino acids, cardiac glycosides, steroids, tannin and phenolic using the standard procedure $[8,9]$.

\section{Microbial strains}

The strain maintained in a sterile condition and grown on Nutrient Agar (NA) for bacteria and Sabouraud dextrose agar (SDA) for fungi in the Microbiology Laboratory, Girijananda Chowdhury Institute of Pharmaceutical Science, Azara, Guwahati, India.

Table 2: Microorganisms used for anti-microbial activity

\begin{tabular}{|c|c|c|c|c|c|}
\hline Bacterial strain & & & & Fungal strain & \\
\hline Gram positive organism & MTCC No. & Gram negative organism & MTCC No. & Name & MTCC No. \\
\hline Staphylococcus aureus & MTCC3159 & Escherichia coli & MTCC1651 & Candida albicans & MTCC2455 \\
\hline
\end{tabular}

\section{Preparation of extract solution}

On the day of experimentation for in vitro anti-microbial activity study, dissolve $0.5 \mathrm{mg}$ of the crude extract in $5 \mathrm{ml}(100 \mu \mathrm{l})$ of $100 \%$ dimethylsulfoxide (DMSO).

\section{Anti-bacterial assay}

The anti-microbial activity of the plant extract was carried out by the paper disc diffusion method. Plant extract was prepared by dissolving in DMSO and sonicated and filtered (Stock: $1 \mathrm{mg} / \mathrm{ml}$ DMSO). A suspension of testing microorganisms was poured on an adequate amount of Muller Hinton Agar medium into sterile plates and allowed to solidify in the refrigerator under aseptic conditions. The plant extract of different solvent (petroleum ether, chloroform, methanol) was impregnated with sterile $5 \mathrm{~mm}$ diameter of whatman no.4 paper discs. The plates were then subsequently incubated at $37^{\circ} \mathrm{C}$ for $24 \mathrm{~h}$. After incubation, all the plates were observed for zones of inhibition and the diameter of these zones were measured in millimetres. All the procedure was performed under sterile conditions. Amikacin $(30 \mu \mathrm{l})$ served as a positive control [10].

\section{Anti-fungal assay}

The anti-fungal activity of plant extract was tested by the paper disc diffusion method. The sabouraud dextrose agar plates were inoculated with Candida albicans by point inoculation. The filter disc $(5 \mathrm{~mm}$ in diameter) impregnated with plant extracts of different solvent and were placed on the test organisms seeded plates. Fluconazole standard disc $10 \mu \mathrm{g} / \mathrm{disc}$ was used for the anti-fungal assay. The activity was determined after $3 \times 24 \mathrm{~h}$ of incubation at $28^{\circ} \mathrm{C}$. The inhibition zones were measured in $\mathrm{mm}$ and compared with that of standard antifungal (Fluconazole) $(10 \mu \mathrm{l})$ which was used as the positive control. All tests were performed under sterile conditions [11].

\section{RESULTS}

The present study shows the phytochemical screening and antimicrobial activity of plant extract of different solvent.

\section{The percentage yield of dried extract}

Percentage yield of petroleum ether extract $=6 \%$

Percentage yield of chloroform extract $=1.71 \%$

Percentage yield of methanolic extract $=3.97 \%$

\section{Phytochemical screening}

The observation made for the phytochemical analysis of the leaf extracts of Thunbergia coccinea are summarised in table 3 and it shows the presence of alkaloid, flavonoid, cardiac glycoside, saponin, tannin and phenolics.

\section{Antimicrobial activity}

Table 4 illustrates the in the vitro anti-microbial activity of the leave extract of Thunbergia coccinea with the standard. The plant extract of three different solvents (petroleum ether, chloroform, methanol) exhibits anti-microbial activity against both gram positive and gram negative bacteria.

Table 3: Qualitative phytochemical screening of the plant extract of different solvent

\begin{tabular}{|c|c|c|c|c|}
\hline Phytochemical test & & Petroleum ether extract & Chloroform extract & Methanol extract \\
\hline \multirow[t]{3}{*}{ ALKALOID } & Mayer's test & - & - & - \\
\hline & Dragandroff test & + & + & + \\
\hline & Wagner's test & - & - & - \\
\hline STEROID & Salkowski test & - & - & - \\
\hline TANNIN AND PHENOLICS & Lead acetate & + & + & + \\
\hline FLAVANOID & Shinoda test & + & - & + \\
\hline CARDIAC GLYCOSIDE & Killer killiani & + & + & + \\
\hline AMINO ACIDS & Ninhydrin test & - & - & - \\
\hline COUMARIN & Flourescence test & - & - & - \\
\hline SAPONIN & Foam test & + & + & + \\
\hline REDUCING SUGAR & Fehling's test & - & - & - \\
\hline PROTEIN TEST & Millon's test & - & - & - \\
\hline
\end{tabular}

$(+)=$ Present and $(-)=$ Absent 
Table 4: Antimicrobial activity of the leaf extract of Thunbergia coccinea against the growth of some pathogenic bacteria by using the discdiffusion method

\begin{tabular}{|c|c|c|c|}
\hline \multirow{2}{*}{$\begin{array}{l}\text { Name of the compounds } \\
\text { with concentration }\end{array}$} & \multicolumn{2}{|c|}{ Anti-bacterial activity diameter of zone of inhibition ( $\mathrm{mm}$ ) } & \multirow{2}{*}{$\begin{array}{l}\text { Anti-fungal activity diameter of zone of } \\
\text { inhibition (mm) } \\
\text { Candida albicans } \\
\end{array}$} \\
\hline & Escherichia coli & Staphylococcu aureus & \\
\hline Amikacin $(30 \mu \mathrm{l})$ & 28.34 & 25.14 & ---- \\
\hline Fluconazole $(10 \mu \mathrm{l})$ & --- & ---- & 26.50 \\
\hline Pet. Ether Extract $(100 \mu \mathrm{l})$ & 17.50 & 15.0 & 17.10 \\
\hline Chloroform Extract $(100 \mu \mathrm{l})$ & 20.0 & 18.50 & 16.20 \\
\hline \multirow[t]{2}{*}{ Methanolic Extract $(100 \mu \mathrm{l})$} & 16.30 & 14.20 & 13.45 \\
\hline & \multicolumn{3}{|c|}{ Zone including $5 \mathrm{~mm}$ of paper diameter } \\
\hline
\end{tabular}

\section{Zone of Inhibition Vs Concentration}

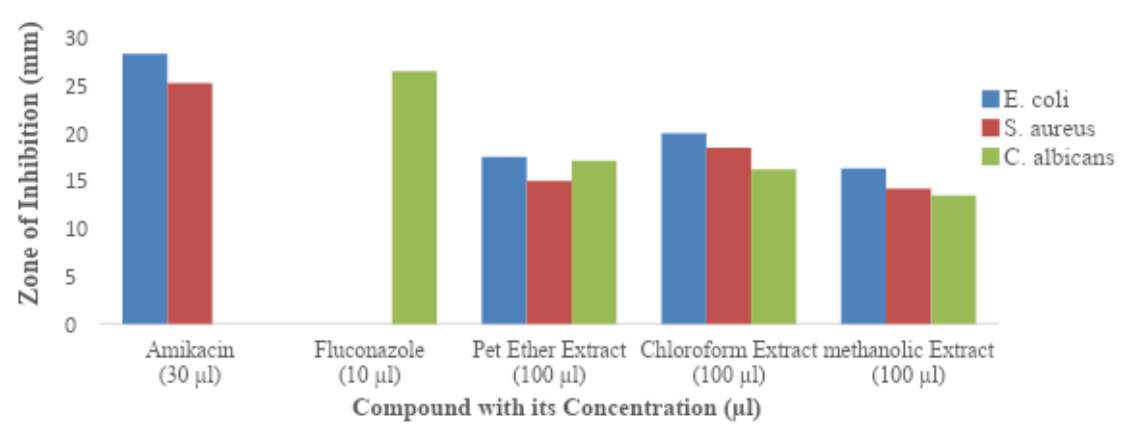

Fig. 1: Zone of inhibition vs concentration

\section{RESULTS AND DISCUSSION}

\section{Phytochemical analysis}

The phytochemical test of the leaf extract of various solvent (petroleum ether, chloroform and methanol) revealed the presence of various phytoconstituent like alkaloid, flavonoid, cardiac glycoside, saponin, tannin and phenolics. The result of the phytochemical test carried out on the extracts were recorded as shown in table 3.

\section{Anti-bacterial and anti-fungal activity}

In this study, one gram positive bacteria (staphylococcus aureus) and one gram negative bacteria (E. coli) were selected for the evaluation of anti-bacterial activity and Candida albicans was selected for the evaluation of the anti-fungal activity of the leaf extracts of Thunbergia coccinea. The leaf extract of different solvent was screened in vitro by agar disc diffusion method using Amikacin as the standard for anti-bacterial activity and Fluconazole as standard for against selected bacterial and fungal strains.

The chloroform extract of the leaf of Thunbergia coccinea showed the highest inhibitory activity against the bacterial strain of Escherichia coli and Staphylococcus aureus. Petroleum ether extract showed moderate anti-bacterial activity and the methanolic extract showed the lowest anti-bacterial activity.

Whereas in the case of fungal strain petroleum ether extract showed the highest inhibitory activity, chloroform extract exhibit moderate anti-fungal activity and the methanolic extract exhibit lowest antifungal activity. The result was shown in table 4.

\section{CONCLUSION}

The result confirms the significant anti-microbial activity of the leaf extract and it contains a substantial amount of phytochemicals. It is anticipated that this study would guide to the creation of some compounds that could be used to develop new and more powerful anti-microbial drugs of natural origin.

\section{ACKNOWLEDGEMENT}

The authors thankful to Dr. Sumit Das, Assistant Professor Department of Pharmaceutical Chemistry, Girijananda Chowdhury Institute of
Pharmaceutical Science (GIPS) Azara, Guwahati, India for his support and guidance provided during this work and Head of the department, Guwahati University for authentication of the plant specimen. Also thankful to Principal and Department of Microbiology, GIPS Azara, Guwahati for conveying this exploration work.

\section{AUTHORS CONTRIBUTIONS}

All the author have contributed equally

\section{CONFLICT OF INTERESTS}

There was no conflict of interest

\section{REFERENCES}

1. Asres $\mathrm{K}$, Taddese $\mathrm{S}$, Gebremariam $\mathrm{T}$. In vitro antimicrobial activities of some selected topically applied medicinal plants of Ethiopia. Ethiop Pharm J 2003;21:34-45.

2. Awaad, Amani S, Soliman GA, El-Sayed, Dalia F, El-Gindi, et al. Hepatoprotective activity of Cyperus alternifolius on carbon tetrachloride-induced hepatotoxicity in rats. Pharm Biol 2012;50:155-61.

3. Medina AL, Lucero ME, Holguin FO. Composition and antimicrobial activity of anemopsis californica leaf oil. J Agric Food Chem 2005;53:8694-8.

4. Romero CD, Chopin SF, Buck G, Martinez E, Garcia M, Bixby L. Antibacterial properties of common herbal remedies of the southwest. J Ethnopharmacol 2005;99:253-7.

5. Duraipandiyan V, Ayyanar M, Ignacimuthu S. Antimicrobial activity of some ethnomedicional plants used by paliyar tribe from Tamil Nadu, India. BMC Complement Altern Med 2006;6:50-4.

6. Djeussi DE, Noumedem JA, Seukep JA. Antibacterial activities of selected edible plant extracts against multidrug resistant gram negative bacteria. BMC Complement Altern Med 2013;13:130-4.

7. Sultana KW, Chatterjee S, Roy A, Chandra I. An overview on ethnopharmacological and phytochemical properties of Thunbergia species. Med Aromat Plants 2015;4:1-6.

8. Tiwari P, Kumar B, Kaur M, Kaur G, Kaur H. Phytochemical screening and extraction: a review. Int Pharm Sci 2011;1:98-106.

9. Ibironke AA, Sarah ON, Adewale A. Anti-microbial activity and phytochemical screening of five selected seeds from Nigeria. Int J Biomed Pharm Sci 2010;4:104-6. 
10. Chetan PS, Murugananthan G, Komaleeswari K. Evaluation of anti-microbial activity of methanolic extract fractions of Delonix elata bark. Int J Res Ayurveda Pharm 2012;3:425-7.
11. Gayathri G, Saraswathy A, Vijayalakshmi K. Anti-microbial activity of medicinal plant Bauhinia variegata linn. Int J Pharma Bio Sci 2011;1:400-8. 